\title{
Some Thoughts on Intensive Spanish Teaching in Internet Environment
}

\author{
Hanghang Xie \\ Xinhua College of Sun-Yat University, Guangdong, Dongwan, 510520, China
}

Keywords: Internet environment, Spanish, intensive reading, teaching, thinking

\begin{abstract}
Since 2013, our country's colleges and universities have started a micro-curriculum based on the network environment. All professions are beginning to try to join the micro-class teaching process in order to improve the efficiency of the curriculum, improve students' ability to learn independently. Spanish Intensive Reading is the main course in the compulsory course for Spanish undergraduate majors. Teachers should pay attention to the introduction of culture in intensive reading teaching so as to cultivate students' intercultural communicative competence. This article explores the method of cultural introduction in intensive reading teaching in Spanish from the aspects of vocabulary explanation, text teaching and extracurricular practical activities.
\end{abstract}

\section{Introduction}

According to the Syllabus for Basic Major in Spanish for Institutions of Higher Learning, the aims of the basic (first and second year) teaching are: (1) to teach students the basics of Spanish; and (2) to conduct a comprehensive and rigorous Spanish study of students Language skills and skillful training; (3) enable students to gain an initial understanding of the culture and national conditions of the Spanish-speaking countries; (4) require students to master the correct learning methods, develop good study habits and have initial independent work Ability, to improve the stage of learning and lay a solid foundation. Among them, the basics of Spanish include speech, vocabulary, grammar and functional ideas and other projects. Basic language skills include listening, speaking, reading and writing four. These two aspects constitute the basic skills of Spanish teaching, which is the basis and premise for language communication. Therefore, in the basic stage of teaching, we must always attach importance to the teaching of language knowledge and listening, speaking, reading and writing of the four basic skills training, solidly lay a solid language foundation.

Intensive reading is an important main course in the basic teaching stage, which carries the heavy responsibility of teaching the basics of Spanish. Including voice teaching, vocabulary teaching, grammar teaching and functional ideas of teaching. At the same time, we should also train students in listening, speaking, reading and writing skills in intensive reading. Therefore, intensive reading in the entire basic stage of teaching occupies an absolutely important position.

Culture is the sum of material and spiritual wealth created by mankind in the course of social and historical development. People living in different cultural environments have different ways of expressing, thinking and living. Language is an integral part of culture and reflects the characteristics of a nation, including its historical and cultural background. Once the language is out of the culture, it will lose its ideological, cultural, intellectual and instrumentalities. According to Palmer, a British linguist, "language loyally reflects the entire history and culture of a nation, faithfully reflecting its various games and entertainment, beliefs and prejudices." American linguist Sapir, in "Language The book states: "Language has an environment which cannot exist without culture and cannot be separated from the traditions and beliefs inherited by society." Thus, language and culture are interdependent and interdependent. To truly master a language, one must understand the social and cultural context in which that language is generated. 


\section{The Proposed Methodology}

Intensive reading teaching specific methods. Spanish is the official language of most Spanish and Latin American countries and one of the six working languages of the United Nations. The countries and regions where Spanish is currently the official language are Argentina, Bolivia, Chile, Colombia, Costa Rica, Cuba, Dominican Republic, Ecuador, El Salvador, Equatorial Guinea, Guatemala, Honduras, Mexico, Nicaragua, Panama, Paraguay, Peru, Spain, Uruguay, Venezuela and Puerto Rico. Spanish is also used in Belize, Gibraltar, the Philippines, Trinidad and Tobago and Western Sahara. This shows that the Spanish language is widely used in the world and its importance in international affairs.

A good intensive reading class should not only complete the transfer of basic knowledge of language, but also improve students' ability of listening, speaking, reading and writing, complete with active classroom atmosphere and active participation of students. In this paper, intensive teaching text string to specifically analyze how to teach students not only in a clear and systematic way to learn vocabulary, grammar knowledge, students can also actively participate in the teacher's explanation, and the teacher to form a good interaction, to achieve Training of listening, speaking, reading and writing abilities.

Foreign language teaching in our country is paying more and more attention to cultivating students' comprehensive ability to adapt to the needs of social development and international exchanges in our country. Intensive Spanish class is the main course in the compulsory course of Spanish undergraduate majors. Its teaching tasks extend from the first grade to the third grade. It has many teaching characteristics such as long class time, strong continuity and comprehensive training of foreign language skills. Teachers in intensive teaching in addition to cultivating students 'language ability, but also pay attention to cultivate students' intercultural communication skills. Can be seen in the Spanish intensive teaching of cultural import is very necessary.

Cultural Introduction in Vocabulary Explanations. Vocabulary is the most basic element of language, but also the most active language component, carrying the very rich cultural information. As Wilkins, a well-known British linguist, put it: "Without grammar, there are very few things people can express." It is boring and pointless to study and learn vocabulary without a contextual culture. Vocabulary teaching in intensive reading requires Semantic meaning of interpretation of the word, so that students grasp the cultural content carried by the vocabulary to stimulate student interest in learning and develop students' intercultural communication skills and the author on a few simple examples of vocabulary to explore how to guide the culture of vocabulary teaching.

Daily necessities, food, things, etc. are a large vocabulary for Spanish beginners to remember. Most of these terms are nouns, carrying the history, customs, festivals and other cultural content as teachers should be good at accumulation and conclusion. For example, tomate m. (Tomato) the word, first of all can start from the origin of tomatoes. Native to Peru, South America and Peru, tomatoes were introduced into Europe and introduced to China by the "Silk Road" in the late 18th century. After that, you can introduce La Tomatina, a famous fiesta about tomatoes in Spain. La Tomanina is the festival held in the town of Bugnol, Valencian Community of Spain, on the last Wednesday of August each year. Tens of thousands of participants came from all over the world for a melee that would not hurt, throwing over 100 tons of juicy tomatoes on the street. Another example is uba $\mathrm{f}$. (Grape), the Spanish New Year a very important celebration of the grape-related. Every New Year night, thousands of people flock to Puerta del Sol in Madrid. With the melodious bell sounded by the ancient bell tower on the Puerta del Sol, everyone swallowed up the 12 grapes in their hands and prayed for good luck in 12 months of the second year. After eating the grapes, people began to drink, dance, sing, and celebrate the festive season until dawn the next day.

At the end of the 15th century, the Spanish colonists brought Spanish to the American continent. After hundreds of years of development and change, gradually formed a distinct characteristic of the Americas Spanish. The Americas are the most widely spoken Spanish. Some of our Spanish-speaking students work in America or America after graduation. Therefore, it is very important for students to understand and master the Spanish language and culture in the Americas from the basic learning stage. Many of the terms in Spanish are very different in usage and meaning in Spain and in the countries of 
the Americas Western Region, and our textbooks generally focus on teaching Spanish in Spain. Therefore, Intensive Reading teachers should pay attention to supplement to explain some of the differences between Spain and the Americas, focusing on the practicality of language. Words such as aciledo (febril), acuerdo (reunión, consejo, consulta), balde (cubo para agua), birome (bolígrafo), boleto (billete), celular ( teléfono móvil, cobija (ropa y abrigo de cama), colectivo (autobús), chapa (cerradura), durazno (melocotón), frijol (judía, habichuela), jugo (zumo), mercadería (mercancía), pollera remera (camiseta), saco (chaqueta), subte (metro), temblor (terremoto), valija (maleta), vidriera (escaparate) and the like. In addition, although many verbs are used in the Americas, their meaning is quite different from that of Spanish, such as apurarse (darse prisa), bregar (trabajar), catar (mirar), coger (significado sexual), cueriar (azotar), demorarse tardar, dilatar (tardar, demorar), pararse (levantarse / ponerse de pie), ponerse bravo (enfadarse), prometer (asegurar), recibirse (tomar grado universitario) and the like.

Courses under the network environment. Micro-curriculum has many advantages and can make up for the disadvantages of many classroom teaching modes, but not all content is suitable for teaching in the form of micro-curriculum. Hu Tie-sheng in the micro-class design of the main principles of the first to emphasize the micro-curriculum topics must be closely linked to a "micro" word. A micro-class can only explain a knowledge point, avoid big and big. At the same time, the production of micro-curriculum, the best choice of teaching the key or difficult content, which is worth the students and teachers spend a lot of time and energy knowledge points, so as to make full use of its advantages and improve classroom efficiency.

Optimize teaching design. Micro-video is really a very important and integral part of micro-curriculums, but not the only one. In order to promote the students to complete the autonomous learning under their own class, besides the micro-video, they should also be equipped with the corresponding syllabus, testing questions and platforms for communication between teachers and students. Syllabus allows students to understand the relevant knowledge of this lesson, such as prerequisites and follow-up knowledge, to a certain extent, to avoid the fragmentation of micro-learning to help students form a knowledge system. A series of test questions can make students and teachers intuitively see the effect of self-learning. A good interactive platform can help students to communicate with teachers in times of difficulties and get rid of the limitations of time and place in the classroom so that teachers can grasp the weak points of students' learning in time so as to provide supplementary explanations in the classroom. At the same time the appropriate set of incentives, but also allows students to form a QA team to solve each other's problems.

Improve the understanding and expression of text language. Language is a communication tool. The basic stage of the text, in addition to grammar and vocabulary teaching, the concept of functional sentences occupy a large part of the function of the concept of expression is very common, is the basic stage for students in communication for the main content.

In order to enable students to communicate properly in Spanish, skills training and communication needs must be combined to create a language communication environment close to life so that they pay attention to the appropriateness of language from the initial stage. For example, if the text appears in dialogues, teachers should arrange for the students to read and train their conversations and pay attention to correcting the students' tone. Let students get rid of "reading gas." When studying numbers, quantity, price, the teacher can arrange the students for dialogue creation and performance. Let students learn the corresponding expressions in the context.

It is possible to compare the expression in Spanish with that in Chinese and achieve the impressing and graceful language of students. For example: Foreign language speech opening address: Señoras y señores, which is consistent with the Chinese expression, the first lady, say Mr.. Another example: after the foreigners meet to say Hola, always ask: qué tal? And our daily greetings between Chinese people is not the way, so the teacher should be as an example, to greet the students before class to add qué tal? Students in the subtle also develop this kind of greeting habits. Another example: If you want to know who answered the phone when you call, you will ask: Con quién hablo? Quién es usted? This difference between Chinese and Western teachers in teaching should pay attention to correct. 
For example, the text of Los Horarios in the fourteenth lesson of "Modern Spanish", Volume I, is for work and rest, and the lesson for the text "La Comida" in Lesson Fifteen is about eating habits. Although both texts refer to the difference between the time in West and our eating habits, the content is relatively simple and general. According to the content and cultural point of the two classes, teachers can supplement the time and place of rest, eating habits, Western etiquette and other original texts in Spanish-speaking countries. Based on the language proficiency of students at this stage, the A2 level "Los Horarios y Las Comidas en Espa a", published in February 2012 by the graded reading electronic journal "Tecla" issued by the Spanish Cultural Office in the United Kingdom Embassy in Great Britain and Northern Ireland is a good one. Not only does the article give a detailed introduction to Spanish schedules and eating habits in simple language, but also feature gourmet pictures and exercises. Teachers through the intuitive pictures, cultural differences between the contrast, you can increase the classroom fun, intellectual, cultural, and cultivate students' intercultural communication skills.

For example, "Una Velada", the second lesson of Book II of Modern Spanish, briefly mentioned the traditional dance in Spain and several Latin American countries. Teachers can broadcast videos of Mexican Mariachi Dance (also known as Hat Dance), Spanish Flamenco Dance, Spanish Seville Dance, Chile Cuikca Dance and Argentinean Tango to students to guide students through the video Find out the scenes you can use the passive passive sentences to practice Grammar points in this lesson. You can also give students a description exercise of dance costumes, performance scenes and actors' movements. In addition, students may be asked to find out the most interesting piece of information about a dance in a Spanish-speaking country and introduce the origin, history and characteristics of the dance to students in oral form. This practice can not only exercise, consolidate the students 'knowledge of the language, but also combine cultural development with language learning to enhance students' ability to use language flexibly.

\section{Conclusion}

As far as Spanish professional teaching in colleges and universities is concerned, basic intensive reading teaching generally focuses on pronunciation, grammar and vocabulary, supplemented by skills training such as listening, speaking, reading and translating. For the higher grades in the target language country literature, history, geography, politics, economics, art, religion, festivals, film and television, music and other content-based learning as the core teaching foundation. Spanish Intensive Reading Teachers must be aware of the importance of combining foreign language teaching and cultural background knowledge with the introduction of culture in teaching from the basic learning stage as a variety of ways to improve students 'sensitivity to culture, and cultivate students' cultural awareness and intercultural communication skills, so that students become a real thick foundation, wide-caliber, complex foreign language talent.

\section{References}

[1]. Gupta, H., Vahid Dastjerdi, A., Ghosh, S.K. and Buyya, R., 2017. iFogSim: A toolkit for modeling and simulation of resource management techniques in the Internet of Things, Edge and Fog computing environments. Software: Practice and Experience, 47(9), pp.1275-1296.

[2]. Wang, Y., Li, J. and Wang, H.H., 2017. Cluster and cloud computing framework for scientific metrology in flow control. Cluster Computing, pp.1-10.

[3]. Oh, J., Park, Y., Choi, J. and Choi, J., 2017, June. A rule-based context transforming model for robot services in internet of things environment. In Ubiquitous Robots and Ambient Intelligence (URAI), 2017 14th International Conference on (pp. 331-336). IEEE.

[4]. Kharkongor, C., Chithralekha, T. and Varghese, R., 2017. Trust and Energy-Efficient Routing for Internet of Things-Energy Evaluation Model. In Proceedings of the 5th International Conference on Frontiers in Intelligent Computing: Theory and Applications (pp. 585-597). Springer, Singapore. 